\title{
Prayer, the encounter and participation, the experience: A Pauline exhortation towards a spirituality of prayer
}

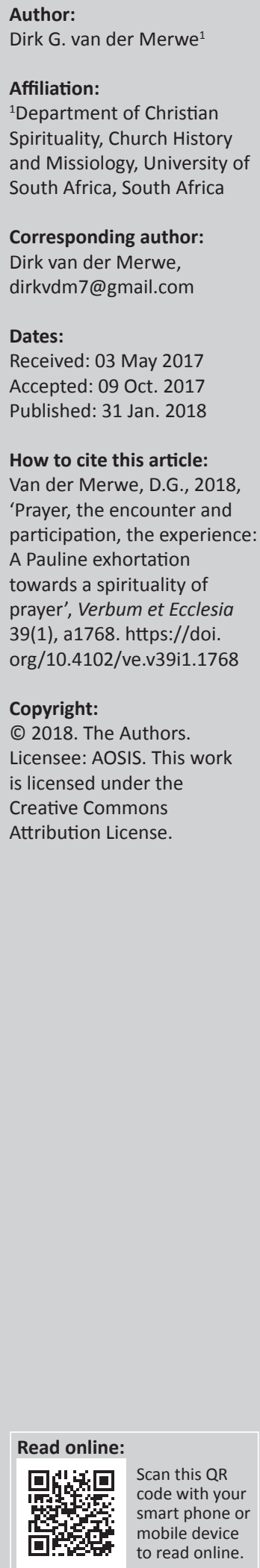

Numerous references to prayer occur throughout the Old Testament and New Testament. These prayers relate closely to particular circumstances and needs where the petitioner appeals to God, illustrating the importance of prayer as part of the dialogue and communication between God (in the image of a Father) and Israel and the Church (in the image of his children). This article investigates Paul's contribution to this dialogue. In 1 Thessalonians 5:17, Paul exhorts (using the imperative) the Thessalonians to pray 'constantly' ( $\alpha \delta 1 \alpha \lambda \varepsilon i ́ \pi \tau \omega \varsigma)$, an exhortation located in the last pericope of the epistle, between two other exhortations (imperatives) indicating time ('always') and space ('all circumstances'). Paul thus uses two more exhortations (surrounding the exhortation, 'pray constantly') to define what he means by 'constant' (without ceasing) prayer. His conviction of this necessity leads him to offer himself as an example of 'praying constantly' when he writes to the community in Thessalonica. Prayers in Paul's epistles focus on the existential needs of daily living, to stand firm against evil and the spiritual need to live pure and blameless lives (complete sanctification) until the parousia. Conclusions arising from Pauline textual references on prayer include: the experience of God is not limited to extraordinary events, but subsists essentially in ordinary daily events; the understanding of God's participation in the lives of believers is not always obvious and comprehensible; the Holy Spirit enables believers spiritually to see, hear and understand God's daily involvement in their lives; and, prayer for the believer facilitates spiritual experiences which provide continuous transformation for the one who 'prays without ceasing'. The result, for Paul, of this form of dialogue and communication between God and his Church, is that regular prayer constitutes joy and thankfulness.

Intradisciplinary and/or interdisciplinary implications: This research relates to the disciplines of New Testament and Christian Spirituality. The focus is how to experiencing dialogue with the divine regularly every day. A specific mindset is needed to accomplish this; a mindset to see, hear and experience the divine in everyday life in the ordinary events in life.

\section{Introduction}

'Prayer is our way of being in the world with God' (Adams 2016:271). According to Hendry (1972:30), 'prayer is the life line of theology' because it is the en route to knowing God. This togetherness of God and the believer can take on the following forms: wordless presence, human knowledge, articulate speech or even joint activities (cf. Adams 2016:273). Just like people are affected by God consciously and unconsciously in their everyday living, they are also consciously and unconsciously interacting with God (Adams 2016:274). Thus, people are tangled up with the divine in everyday life. Their functional being is not 'solo', but a duet. Considering that God is a trinity, it should then rather be a quartet (Adams 2016:275). William James (1902:505) refers to prayer as 'the very soul and essence of religion'. Via prayer, a believer attempts to create a significant relationship with a deity. Different forms of prayer add different values and effects to the meaning of the prayer (cf. Whittington \& Scher 2010:59). The form of prayer chosen by the one who prays reflects the mood or even the need of that person (cf. Garrett 1972:14).

Prayer and divine involvement, ${ }^{1}$ and the experience of it by the believer, constitute divine-human dialogue within their relationship. They (prayer and divine involvement) are like the two sides of a coin - you can distinguish them but never separate them. The one implies the other. In this

1.This research was presented as a paper firstly at the Biennial Meeting of the Society for the Study of Christian Spirituality in Kappel, Switzerland, in June 2017 with the conference theme, 'Pray without ceasing', and later at the SPIRASA annual conference at St. Augustine College, Johannesburg, during October 2017.

Note: This article is meant to be read as a paper at the Third International Ecumenical Conference of the Center for the Academic Study of Christian Spirituality and the Bi-annual International Conference of the Society for the Study of Christian Spiritualty at Zurich University, June 2017. The theme of the conference is 'Pray without ceasing. Perspectives in spirituality studies'. 
article, I endeavour to point out the nature of this dialogue, for this is the vitality behind 'prayer without ceasing' in much of the Christian tradition.

This article will focus on three things. Firstly, Paul's prayer life will briefly be scrutinised. This information will constitute a better understanding of his exhortation in 1 Thessalonians 5:17 to 'pray without ceasing'. Secondly, the first aspect mentioned in the title, 'Prayer, the Encounter', will be investigated. Thirdly, the second aspect mentioned in the title, 'Participation, the Experience', will be discussed.

\section{Paul and prayer}

In his epistles, Paul repeatedly refers to his prayers (especially for the particular church to which he is writing). ${ }^{2}$ For Hardin (2015:137), these prayers form the most notable aspect of Paul's spirituality. According to McGee (2002:1), Paul is the ultimate example to follow when praying. ${ }^{3}$

The following points summarise Paul's prayer life. Firstly, to Paul the object of prayer is always God - and not Christ (McGee 2002:6; also Garrett 1972:3-17; Hardin 2015:138). This is true regarding Paul's doxologies, thanksgiving and his life of prayer. Each introduction of his prayers starts with thanksgiving to God (Rm 1:8; Phlp 1:3; also cf. 1 Cor $1: 4 ; 1$ Th 1:2). Stendahl (1980:247) points out that Paul's life and his mission 'is totally conditioned by what God has done in and through Jesus Christ whom God raised from the dead'. Secondly, Paul consistently refers to God as 'Father' in his prayers, which relates to God as being the Father of Jesus and likewise the Father of Christian believers. $^{4}$

Thirdly, Paul's prayer language has been used quite normatively throughout the history of the church, and even so today. Christian believers today are certainly not apostles as Paul used to be. They have not seen and experienced the resurrected Christ as Paul did (Ac 9:3-9). The world today is not the world of Paul; yet, the church can learn much from him. Believers are motivated to regular prayer when reading his epistles. Christian believers use his language when praying. The church has learnt from Paul how to be a caring community through intercession and how to rejoice and be grateful in God's involvement in the personal lives of believers (cf. Phlp 4). Today we can only wonder what

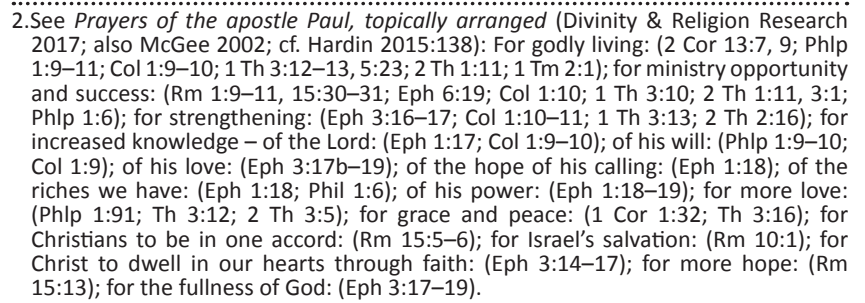
15:13); for the fullness of God: (Eph 3:17-19).

3.In the next subsection, I will elaborate on this statement in more detail.

4.Stendahl (1980:246) points out after consulting the work of Jungmann, that the Western church has preserved the Pauline point of view of praying. They directed all their prayers to God, in the name of Jesus Christ. They never pray to Christ or to the Holy Spirit. Jungmann (1976) studied the prayers of the church throughout history. it would have sounded like when Paul was praying (cf. Stendahl 1980:248).

Fourthly, if spirituality can briefly and basically be defined as the 'experience of the divine' in the believer's everyday life of devotion, then the spirituality of Paul takes on a practical value linked to Paul's prayers. Paul's entire life was a regular engagement in spiritual practices which cherished the experience of the divine in his daily life, and resulted in Paul regularly praying. This view relates to Hardin's understanding of spirituality. According to Hardin (2015:134), Christian spirituality is to be found in 'what is common and mundane more so than in that which is ecstatic and mystical'. It is all about partnership with the Spirit.

Fifthly, Fee (1996:147; also Hardin 2015:137) points out 'that Paul was a pray-er' before he became a missionary and thinker. Fee is convinced that his habit of praying constituted the connection between his old life in Judaism and his new life in Christ. Hardin (2015:137) substantiates and verifies this statement by Fee, referring to Paul's descendance from the Pharisaic holiness tradition, where he was from an early age educated to pray. Faithful Jews were to recite the Shema twice a day (Dt 4:6-9), probably also the Amidah (the 18 Benedictions). No recorded prayers occur in Acts; however, Luke notes that Paul prayed 'constantly'. He prayed during his conversion (Ac 9:11); he prayed in the Philippian jail (Ac 16:25); he prayed with the elders at Ephesus (Ac 20:36) and with the disciples in Tyre (Ac 21:4). He also prayed in the temple in Jerusalem (Ac 22:17) and on the island of Malta (Ac 28:8), and obviously for all the churches he founded (cf. Fee 1996:140-151).

Sixthly, because of his theological education, some of his prayers are saturated with meaningful theological concepts and vocabulary (Hardin 2015:138), as also with aspects of everyday life.

Finally, Paul exhorts his readers to pray constantly. In 1 Thessalonians 5:17 he exhorted them to pray constantly, and in 1 Thessalonians 3:10 he sets them an example by saying, 'Night and day we pray most earnestly'. Then, also in Ephesians 6:18, ${ }^{5}$ it is written that Paul had said: 'Pray in the Spirit at all times in every prayer and supplication. To that end keep alert and always persevere in supplication for all the saints'. Because of his own regular practice of prayer and his subjective experiences of God in his everyday life, Paul could exhort the believers in Thessalonica to pray without ceasing.

\section{Prayer, the encounter}

Why then did Paul exhort the Thessalonians to 'pray without ceasing'? The meaning of words, phrases and sentences can only be deduced from their immediate linguistic and literary

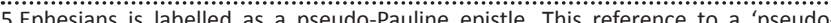
Pauline epistle' is a debatable issue. This author does not want to become involved in this debate here. There are also good and legitimate reasons, posed by many in this debate here. There are also good and legitimate reasons, posed by many
scholars, who do not agree on this point. In this article the conventional point of view, with regard to the authenticity of Pauline epistles, is respected. 
contexts. Therefore, to answer this question one has to look at what Paul has written in the macro-literary ${ }^{6}$ (chs. 4-5) and micro-literary (1 Th 5:16-18) ${ }^{7}$ contexts of this epistle to the Thessalonians. The macro-literary context constitutes the context which helps to understand Paul's exhortation to 'pray without ceasing'. Why this exhortation? In chapters $4-5^{8}$ Paul exhorts the readers to sanctify themselves (ethical exhortations) - to live holy lives. According to the content of these two chapters, holiness is embedded in everyday living, the believer's everyday conduct.

The readers are called to sanctify themselves in order to prepare them for the parousia (1 Th 4:13-15:11, 23). In 1 Thessalonians 3:13 Paul writes, 'And may he so strengthen your hearts in holiness that you may be blameless before our God and Father at the coming of our Lord Jesus with all his saints'. Paul expected the parousia to realise in his lifetime, therefore these strong exhortations to sanctification. In these two chapters $(1 \mathrm{Th} 4,5)$ the themes of parousia and sanctification run parallel.

In 1 Thessalonians $4-5$ occurs the word 'holiness' twice ( 1 Th $4: 4,7,5 ; 26)$, 'how you aught to live' once (1 Th 4:1), 'sanctification' once (1 Th 4:3), sanctify once (5:23), the 'will of God' twice (1 Th 4:3, 5:18), 'blameless' once (1 Th 5:23) and 'to please $\operatorname{God}^{\prime 9}$ (1 Th 4:1) once. Chapter 4 starts with these semantically related references to holiness, and chapter 5 ends with holiness, with a high number of exhortations which concern daily life in between. Thus, in the macrocontext of chapters $4-5$, the exhortation to 'pray without ceasing' relates closely to everyday sanctification. In 1 Thessalonians 4 and 5, a large number of ethical exhortations (imperatives) occur.

6.1 Thessalonians 4:3: 'For this is the will of God, your sanctification: that you abstain from fornication; ... 4 that each one of you know how to control your own body in holiness and honor, ... 5 not with lustful passion, ... 6 that no one wrong or exploit a brother or sister in this matter, ... 7 For God did not call us to impurity but in holiness. 9 you yourselves have been taught by God to love one another. 12 hes. ... 9 you yourselves have been taught by God to love one another; ... 12 ... behave properly toward outsiders and be dependent on no one.' 1 Thessalonians 5:12: .. respect those who labor among you, and have charge of you in the Lord and admonish you; ... 13 esteem them very highly in love because of their work. Be at peace among yourselves. 14 And we urge you, beloved, to admonish the idlers, encourage the fainthearted, help the weak, be patient with all of them. 15 See tha none of you repays evil for evil, but always seek to do good to one another and to all ... 22 abstain from every form of evil. 23 May the God of peace himself sanctify you entirely.'

7.1 Thessalonians 5:16 'Rejoice always, 17 pray without ceasing, 18 give thanks in al circumstances; for this is the will of God in Christ Jesus for you'. See also 1 Thessalonians 5:19 'Do not quench the Spirit. 20 Do not despise the words of prophets, 21 but test everything; hold fast to what is good'.

8.The literary structure of 1 Thessalonians comprises the following: Prescript (1:1) Thanksgiving (1:2-3:13); Ethical exhortations (4:1-5:22); Benediction (5:23-5:28) (Martin 1995:44)

9.The message that Paul communicated to the Thessalonians included firstly God's call to salvation (2:13.2 Th 2:14) and secondly, it included the divinely inspired moral to salvation $(2: 13 ; 2$ Th $2: 14)$, and secondly, it included the divinely inspired moral teaching that authoritatively guided them about their consequent conduct. The
content of that moral tradition was that they had to walk (to live) accordingly and to content of that moral tradition was that they had to walk (to live) accordingly and to
please God. Both of these verbs occur in the present infinitive mode. This implies that coherent and consistent god-pleasing behaviour was expected from them (Martin 1995:119; cf. Ellingworth \& Nida 1976:76). The verb $\delta \varepsilon \tilde{~(' o n e ~ o u g h t ~ o r ~}$ should', Arndt et al. 2000:214) was frequently used where an author wants to underline a particular conduct, which is in particular enacted by God (Mt 18:33; Lk $2: 49,15: 32,18: 1 ;$ Ac 5:29; Tit 1:11). The New Testament is also saturated by $\delta \varepsilon \tilde{c}$ to refer to certain events that must happen because of the divine will (Mt 17:10, 24:6, 26:54; Mk 9:11, 13:7, 10; Lk 4:43; 21:9; Jn 3:14, 30, 9:4, 10:16, 20:9; Ac 1:16, 3:21 4:12; Rm 1:27; 1 Cor 15:53; 2 Cor 5:10; Rv 1:1, 4:1, 22:6). Such conduct was compulsory for the (Green 2002:185) source of the teaching was the divine (as implied by the verb 'received' and vource of the teaching was the divine (as implied by the verb 'received' and verly Christians was to walk (see $2.12,4.12,2$ Th $3.6,11$ ) or conduct themselves in a way in a way that plase in a way that places the divine interests prior in a person's life. Henceforth, Christian will serve God as his slaves (1:9). The principles governing their lives comprise those that he establishes (4:5; Green 2002:186)
Among all these exhortations, it seems that the three exhortations in 1 Thessalonians 5:16-18 form a group or cluster on their own. They constitute the micro-context (1 Th 5:16-18) where prayer liaises with joy and thankfulness (Bruce 1998:125). Joy and thankfulness help us to understand the exhortation to pray without ceasing even more specifically. Sanctification relates the exhortation to pray to a person's entire daily life, as it is evident from these two chapters (chs. 4-5), while the two verbs 'to rejoice' and 'to be thankful' relate unceasing prayer to the experience of the divine during a life of sanctification. This trilogy (joy, prayer, thankfulness) relates prayer to time and space, and also attitude (see 1 Th 5:14-15).

Paul deviates from the directives about the social responsibilities of the believers in the immediately preceding verses ( $1 \mathrm{Th}$ 5:12-15) and turns to the conventions that characterise more in particular Christians' relationship with God. He refers in these verses to three important characteristics of Christians, namely, joy (1 Th 5:16), prayer (1 Th 5:17) and gratitude (1 Th 5:18). A person with these characteristics, according to Paul, lives in agreement to the will of God (1 Th 5:18)..$^{10}$ Paul, in connecting these three exhortations, urges the Thessalonians that they should constantly rejoice, pray and give thanks. This should be their attitude ('continuously', 5:17), the case at all times ('always', 5:16) and in every situation ('in all circumstances', 5:18) (Green 2002:257).

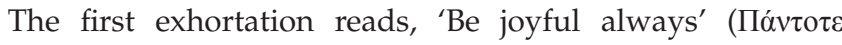

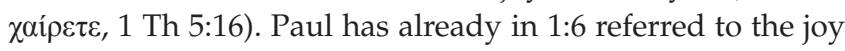
among the Thessalonians, even as they face suffering (1:6b; cf. Mt 5:11-12; Lk 21:28; Ac 14:17; 2 Cor 4:8-10; Col 1:11, 24; 1 Pt 1:6, 4:13; Green 2002:257). For Paul this joy should always be in their lives, irrespective of their circumstances (Phlp 3:1, 4:4). Paul also refers to it as part of the 'fruit of the Spirit' (Gl 5:20). In the New Testament, joy is often coupled with sorrow or suffering (e.g. Phlp 4:4-7; Larson 2000:74).

Antiquity also faced the brokenness of this world. Only the nature and intensity of this brokenness differed from our experience of it. They experienced misery, of which some misery was inescapable, such as death, physical and emotional suffering. An attitude of profound pessimism concerning life was distinctive during Mediterranean antiquity. This pessimism also characterised the inhabitants of the world of Jesus and the world of the apostle Paul. It overlapped in both 'abundance and of famine, of peace and of war, of blessing and of epidemics' (Bloomquist 2007:271). This ambiance of pessimism existed because suffering was interpreted and experienced as a prelude to and a herald of death (Bloomquist 2007:271). Such pessimism was evident in the encounter with mortality. In the ancient Mediterranean world, pessimism also saturated institutions such as family life, the polis, as well as the Roman empire itself.

The frequent references to joy in Paul's letters overruled the brokenness of antiquity. For Paul, joy is a characteristic of a

10.For Bruce (1998:125), rejoicing, prayer and thanksgiving express the sanctifying work of the Spirit. 
healthy Christian life. ${ }^{11}$ Joy is part of the work of the Spirit in the believer (Gl 5:22). He sees Christian joy to be the opposite of self-centeredness. The believer rejoices in the good fortune of others ( $\mathrm{Rm} \mathrm{12:15)}$ and also when people were obedient to the Lord (Rm 16:19; 1 Cor 13:6; 2 Cor 7:9, 13:9; Phlp 4:10). Good Christian company causes joy (1 Cor 16:17; Phlp 2:28). Paul rejoiced even during personal distresses (2 Cor 6:10; cf. 1:6; Phlp 4:4.) and when the Gospel was spread as well as when it involved a form of self-sacrifice (Phlp 1:18; 2:17-18; cf. 2:19-20; 3:6; Martin 1995:181).

Paul never expected any believer to deny that hardships could cause unhappiness (see 1 Th 4:13; 1 Pt 1:6; Rm 12:15). On the contrary, believers recognise that in moments or situations of distress God's presence through his Spirit can imbue believers with joy and with hope. This joy is embedded in God's involvement (Phlp 4:4-8; also Lk 2:10-11) in the circumstances of people, sometimes as a result of prayer (Phlp 4:6-7). Consequently, joy became one of the major distinctive features of Christian communities. The church was distinctive in proclaiming joy to be the nucleus of its faith (see Rm 14:17). The two sources of Christian joy were its rootedness in the gospel and God's involvement in the lives of believers. It was also embedded in hope, and matured in the relationship of the believer with God (cf. Martin 1995:181).

The second exhortation is to 'pray without ceasing' ( $\dot{\alpha} \delta 1 \alpha \lambda \varepsilon i ́ \pi \tau \omega \varsigma \pi \rho \circ \sigma \varepsilon v ́ \chi \varepsilon \sigma \theta \varepsilon, 1$ Th 5:17). In the New Testament, a variety of Greek words are used, which have been translated in English as, only, prayer: in the influential Dictionary of New Testament Theology (Brown 1976:855-886), a number of New Testament scholars discussed these different words; to

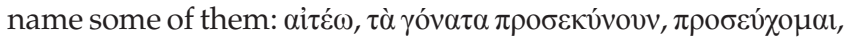
$\delta \varepsilon \dot{\varepsilon} \mu \alpha \mathrm{l}, \pi \rho \sigma \sigma \kappa v \varepsilon \dot{\varepsilon} \omega$. Probably the most familiar term is

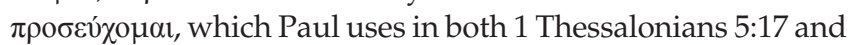
Ephesians 6:18.12 Arndt, Danker and Bauer (2000:879) define the verb $\pi \rho 0 \sigma \varepsilon v ́ \chi 0 \mu \alpha r$ as 'to petition deity, pray'. The semantic dictionary of Louw and Nida (1996:I, 408) defines this verb as 'to speak to or to make requests of God- "to pray, to speak to God, to ask God for, prayer"'. For Zodhiates (2000:4336) it has the meaning of 'to wish, pray. To pray to God, offer prayer. In the NT this comp[ound] verb almost totally supplants the simple verb eúchomai in designating "to pray"'. Friburg, Friburg and Miller (2000:IV, 333) clarify it 'as a religious technical term for talking to a deity in order to ask for help, usually in the form of a request, vow, or wish, pray, speak to (God), ask (MT 6.6)'. Hendriksen and Kistemaker (19532001:138) explain prayer as the "'taking hold on God" in the midst of all circumstances of life'. Thus, in summary, we can

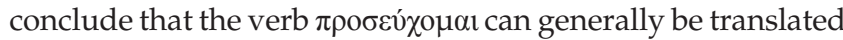
as 'prayer', which can be interpreted as 'a religious technical term for talking to a deity' (Friburg et al. 2000:IV, 333).

Paul's prayer life is expressed customarily in his greetings, his doxologies, and in his confessional language. In all

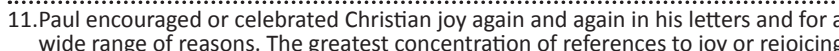
wide range of reasons. The greatest concentration of referen
is found in Philippians, notably written while Paul was in jail.

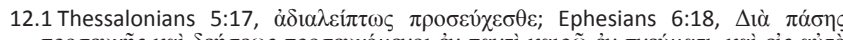

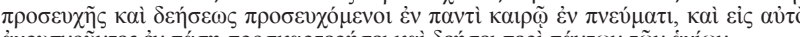

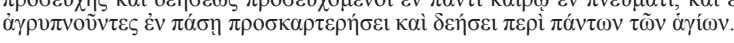

the occurrences, thanksgiving deems to be the primary feeling and mode (Stendahl 1980:241). These greetings and doxologies are carefully shaped by the daily issues and concerns at hand. Further, it must be borne in mind that Paul's epistles are closely tied to this mission (Stendahl 1980:248). Paul's apostolic ministry consists of travels. It is evident from his epistles that Paul's hopes and disappointments about his travels and plans played a significant role in his life of prayer, as it did in his understanding of his ministry. The invitation to the Roman

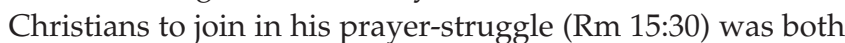
rhetorical and also because of his frustration as to his itinerary (see e.g., 1 Th 2:18; 3:10-11; Rm 15:23; cf. 1:10; Stendahl 1980:243).

It would be a fallacy to understand Paul's teaching about prayer as appropriate what the Christian should pray about. Believers have to perceive that Paul was 'caught up in his work' and accordingly his prayers. Paul's prayers are the prayers of an apostle, a missionary with eschatological urgency in mind (1 Th 4:13-5:11, 23; cf. also Rm 15).

Paul not only exhorted his readers to pray, but to pray 'unceasingly' ( $\alpha \delta 1 \alpha \lambda \varepsilon i ́ \pi \tau \omega \varsigma, 1$ Th 5:17). Arndt et al. (2000:20) translate this adverb as 'constantly, unceasingly'. In their semantic dictionary, Louw and Nida (1996:I, 660) declare it as 'pertaining to not ceasing from some continuous activity "not ceasing, not stopping, unceasingly, continuously"'. Friburg et al. (2000:34) also define this adverb as unceasingly, continuously. From these lexical definitions, it is evident that the two words unceasingly and continuously occur in all of these definitions. A literal understanding of this phrase, 'pray without ceasing', would imply to interpret prayer as an activity that is going on and on, without halting. This is certainly not what Paul had in mind or what he was doing.

The adverb $\dot{\alpha} \delta 1 \alpha \lambda \varepsilon i ́ \pi \tau \omega \varsigma$ [unceasingly] already occurs in 1:2, where it is translated as 'constantly' (New Revised Standard Version [NRSV]). Paul uses this adverb here as a hyperbole to generate a similar sense as when Jesus commanded his disciples that 'they should always pray and not give up' (Lk 18:1). It also relates to another Pauline exhortation to the Romans, that they should 'persevere in prayer' (Rm 12:12; Eph 6:18; Col 4:2). This is precisely what the apostles themselves did for the churches (1 Th 1:2-3, 2:13, 3:10; 2 Th 1:11 and Rm 1:9; Green 2002:258). For Paul, prayer should be a usual and regular activity in the daily lives of the believers in Thessalonica. ${ }^{13}$ The translation of this phrase would then be 'pray regularly' or 'pray frequently'. Paul actually calls on believers to talk to God on a regular basis, for this to become a way of life, just as it is the case with rejoicing and giving

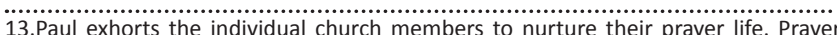
should form part of their personal spiritual exercises (Rm 12:12; Phlp 4:6). He and his colleagues prayed together regularly (1:2; 2 Th 1:11; Rm 1:10). Prayer also eatured in both the assembly's public worship (Martin 1995:181) and in hanksgiving (1 Cor 14:15-17). Thus, from his epistles, it is clear that Paul expected from believers, both privately and in the public assembly, to approach God with 'praise, intercessions, requests, and thanksgiving' (Martin 1995:182). 
thanks. ${ }^{14}$ It should be the regular flow of Christian living regular dialogue with God. The question that arises is how such a way of prayer is viable. This question is answered in the following subsection of this contribution (Participation, the experience).

Differently from the pagans ${ }^{15}$ in antiquity, Christian prayers started with articulating their confidence in God as their Father. They believed that in the familia Dei relationship, God wants to be good to his children (Mt 6:9-13, 7:7-12). They then experience this goodness of God's involvement in their daily lives (Phlp 4:4-7). These early Christians believed that this involvement of God was the foundation of Christian prayer (Green 2002:259).

The third exhortation is to 'give thanks in all circumstances'

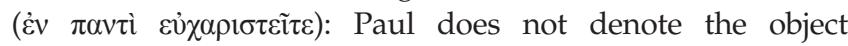
which is to receive the thanks; it may be assumed that Paul has God in mind. This idea also occurs elsewhere in the corpus Paulinum. Habitually, Paul introduces his letters with thanks to God for the churches (Rm 1:8; 1 Cor 1:4; Phlp 1:3; 1 Th 1:2; 2:13; see also Col 1:3; 2 Th 1:3). In 1 Thessalonians, Paul encourages the Thessalonians to express their thanks to God. For Paul, this should be a fundamental quality of their relationship with God. In early Christianity, offering thanks to God was a significant component in Christian worship (Mt 26:27; Mk 8:6; Lk 22:17, 19; 1 Cor 11:24). With the reference to thanksgiving in 1 Thessalonians 5:18, Paul emphasises daily thanksgiving to God. In Ephesians 5:20, Paul calls on believers to 'always [give] thanks to God the Father for everything, in the name of our Lord Jesus Christ'. For him thanksgiving should characterise the Christian life (cf. Eph 5:20; Col 2:7, 3:17), similar to joy and prayer as constants in their lives (1 Th 5:16-17) (Green 2002:259). ${ }^{16}$ Paul refers frequently in his letters to his prayers of thanks for the churches to whom he is writing. This occurs in both private devotions and public pronouncements, encouraging continued praiseworthy behaviour. Paul's explicit references to thanksgiving would have served as an example of gratitude to the readers. According to Martin (1995:182), all Christians should follow this custom.

Paul exhorts the believers to 'give thanks in all circumstances' (1 Th 5:18) to God, and certainly not only when they benefit

14.According to Fairbrother (2016:323), prayer has to become a discipline in the believer's life. For him it has to be 'a rhythm founded on obedience and discipline that is part of the process toward gaining that perfect freedom in Christ that scripture promises'. The concept of 'discipline' has the connotation of rules and scripture promises'. The concept of 'discipline' has the connotation of rules and
regulations. There must be a pattern. In my opinion, believers should also pray at regulations. There must be a pattern. In my opinion, believers should also pray at
random. Prayer, regular prayer, must be spontaneous, just as we find spontaneous random. Prayer,
dialogue in life.

15.Prayer was a common activity of religion during the first century A.D., also among pagans. Christian prayers could be distinguished from pagan prayers in that pagan prayers attempt to influence the gods to be good towards their petitioners (Green 2002:33-34). Their prayers included 'invocations of the deity, worship, and petitions' (Green 2002:258). Along with sacrifices, prayers were commonplace in the pagan cult. Prayers, both private and in public, occurred frequently in that world. For those pagans, the presence of the gods occupied a significant and fundamental place in the consciousness of the people (Ferguson 2003:181-183 also Green 2002:259)

16.Green (2002:259) points out that thanksgiving to ancient gods was a normal practice and occurred regularly in ancient religions, in Judaism as well as in paganism. See Green (2002:259) for references to texts and inscriptions regarding thanksgiving offered to the gods for favours received from them. According to Green (2002:259), deities were regarded to be the supreme benefactors of humanity. The obligation of those who received abundance was to return thanks, humanity. The obligation of those who received abundance was to return thanks,
always with the hope of future benefits. 'The law of reciprocity dominated the exchange of gifts? and thanks' (Green 2002:259). or receive something good from God (Green 2002:259). This exhortation, however, concerns giving God thanks for everything that befalls them. ${ }^{17}$ His motivation is, 'for this is the will of God in Christ Jesus for you'. The Christian approach should be for believers to put their trust in a sovereign God who can turn any situation to work for good (Rm 8:28). This God can make anyone triumphant in any hardship or stressful circumstance ( $\mathrm{Rm}$ 8:31-39; Green 2002:260). Important is for the believers to 'rejoice always, pray without ceasing, give thanks in all circumstances': they should have an attitude to recognise and experience ${ }^{18}$ daily God's involvement in their lives. ${ }^{19}$ Regular prayer, then, is part of the believer's response to an ongoing partnership with the divine. Howard (2008:195-228) noted that when God acts and is involved in the believer's life, the believer responds, on which God again responds to the believer's response.

For Green (2002:260; also Wanamaker 1990:201), Paul relates the Christian characteristics of joy, prayer and thanksgiving to what God has called them to: 'for this is God's will for you in Christ Jesus' (1 Th 5:18). There is no reason to limit this statement in particular to the last of the three exhortations of the trilogy. Wanamaker (1990:200; also Bruce 1998:125; Green 2002:260; Larson 2000:75) argues that 'the parallel imperatival form of all three indicates an equal stress on each one' ${ }^{20}$ The

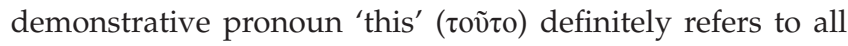
three previous exhortations and not only to the last exhortation 'to give thanks to God'. Intrinsically, the pronoun can also refer to the other exhortations (imperatives) in chapters 4 and $5 .^{21}$

In 1 Thessalonians 4:3-4, Paul links the 'will of God' with sanctification. Sanctification concerns moral requirements to which Paul calls the Christians in Thessalonica. ${ }^{22}$ Then, at the end of 1 Thessalonians 5:23, he indirectly links the 'will of God' with 'holiness' and 'blamelessness' (cf. Green 2002:260). The inner attitude and spirit of the believer is brought into conformity with what God wants (Best 2003:236).

17.The Stoics believed that fate played a crucial role in the lives of people. Fate would destine them to what should be their lot. They also believed that 'the universe was rational and moved according to good purposes. Therefore, whatever happened in life was precisely what was supposed to happen'. The Stoic response was to make the best of every situation (Green 2002:260).

18.At the end of the 20th century, Johnson (1998:12-26; also Hurtado 2000:184) referred to religious experience as a 'missing dimension' in New Testament scholarship. Czachesz (2015:6) points out that at the beginning of the 21st century, an interest developed regarding religious experience and was dealt with in biblical materials (Batluck 2011; Craffert 2008; Davila 2002; Hurtado 2000; Pilch 1996, materials (Batluck 2011; Craffert 2008; Davila 2002; Hurtado 2000; Pilch 1996,
2011; Räisänen 1999, 2000; Theissen 2007, 2013). The publication of Dunn in 2011; Räisänen 1999, 2000; Theissen 2007, 2013). The publication of Dunn in
1970, Baptism in the Holy Spirit, and his publication in 1975, Jesus and the Spirit, 1970, Baptism in the Holy Spirit, and his publication in 1975, Jesus and the Spirit,
certainly contributed to the current interest in 'religious experience' within early certainly contributed to the current
Christianity. See also Fee (1994).

19.According to Czachesz (2015:9), subjective religious experience inspires behaviour. Beliefs shape the memory of religious experience and influences the experiences, while the memories of experience shape beliefs.

20.Wanamaker (1990:199) categorises the three exhortations as 'religious duties'. He also observes that each of the three commands 'either has its source in God ... or is directed toward God'. Best (2003:234) links 1 Thessalonians 5:16-18 with the preceding parenthesis. According to him, 1 Thessalonians 5:12-15 concerns behaviour towards others, while 1 Thessalonians 5:16-18 deals with the inner life of a believer. Because the outer attitudes (1 Th 5:12-15) are shaped by the inner life (1 Th 16-18), the two passages are complementary to each other.

21.The 'will of God' relates semantically to the references of 'holiness', 'sanctification' and 'blameless', occurring in 1 Thessalonians 4-5.

22.Cf. Mark 3:35; Romans 12:2; 2 Corinthians 8:5; Ephesians 6:6; Colossians 4:12; 1 Thessalonians 4:3; Hebrews 10:36; 1 Peter 2:15, 4:2; 1 John 2:17. 


\section{Conclusion of this sub-section}

The imperatives, 'be joyful' ( $\chi \alpha i ́ \rho \varepsilon \tau \varepsilon)$, 'pray' ( $\pi \rho \circ \sigma \varepsilon v ́ \chi \varepsilon \sigma \theta \varepsilon)$

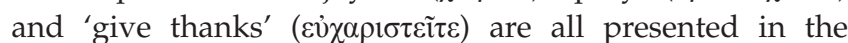
present tense, implying continuous or recurring activities. The two adverbs 'always' ( $\pi \alpha ́ v \tau o \tau \varepsilon)$ and 'continually' ( $\dot{\alpha} \delta 1 \alpha \lambda \varepsilon i \pi \tau \omega \varsigma)$, and the adjective 'in all, every' ( $\pi \alpha v \tau i)$ complement one another and strengthen the message that these actions should consistently characterise the Christian life anywhere (cf. Martin 1995:181). These three qualities are mentioned together purposefully by Paul - the one constitutes and influences the other. Paul's prayers are then the consequences of joy and include gratitude for both God's act in Jesus Christ and everyday living. Principally, Christians have a vital raison d'être to continuously share that joy and gratitude (Stendahl 1980:249).

The question that arises now is: How is it possible to pray without ceasing?

\section{Participation, the experience}

Making it possible: The noun 'participation' in the sub-title also could have been called 'involvement'. Most important for consistent or regular prayer (prayer without ceasing) is to experience divine involvement in everyday life. ${ }^{23}$ In Colossians ${ }^{24}$ it is written that Paul prays that God must increase the knowledge and understanding of the will of God. This should help Paul's readers to discern the en route of sanctification, to please God (Col 1:9f.; Hardin 2015:136).

When Paul then exhorts his readers to 'pray without ceasing', it requires a particular mindset to become aware of divine presence or to experience divine involvement in one's life, and consequently to respond to this via prayer. This is what Paul has promulgated according to Ephesians 4. Believers must learn to reach out to God as part of a personal relationship, or dialogue. This can happen formally as well as informally. Formally, it can happen by showing love to others, praying through Scripture by questioning and disputing God's word, worshipping with hymn singing and prayers from Scripture, as well as in liturgy. Consciously and unconsciously, any form of intentional engagement opens up God's presence to believers. This then becomes a way of being in the world with God. Informally, believers can also experience God's presence and involvement in their lives in everyday living. Even if believers did not hear voices or see visions, they can say that their hearts have been 'strangely warmed' (cf. Adams 2016:276). Believers should see their relationship with God as a partnership that promises great enjoyment to experience God's involvement in their lives

23.Alston (1982) refers to divine involvement as "the effect that God, as conceived in theistic religions, is doing something that is directed to the subject of the experience that God is speaking to him, strengthening him, enlightening him giving him, courage, guiding him, sustaining him in being, or just being present to

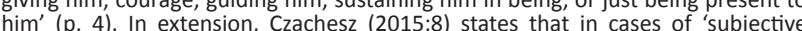
religious experience' we have no direct access to experience itself but only the religious experience' we have no direct access to experience itself, but only the subject's memory. Although recording physiological states ochnology', still the implicit). This again is based on the remembrances of the subject.

24.Colossians is regarded by some scholars, such as Schnelle (2003:44), to be a pseudo- or deutero-Pauline letter.
(Adams 2016:278). This then requires regular responses from believers, which will emanate in regular prayer as a response to the believer's enjoyment and thankfulness of God's involvement in this person's life.

Believers regard the seeing, hearing and experiencing of God's activities in life and divine involvement in their lives, with eyes of faith, as a gift. It is the Spirit of God that enables them to distinguish and experience God's activities and involvement. The Spirit both inspires and enlightens human understanding. See John 6:63: 'It is the spirit that gives life'. This Spirit is also the 'Spirit of truth' ('who will guide you into all the truth', Jn. 16:13). In 1 Corinthians 12:3, Paul also says that 'no one can say "Jesus is Lord" except by the Holy Spirit'. It is only through eyes of faith that believers can see Jesus as the Son of God. Without the Spirit, people will only see Jesus as a first-century rabbi. In 1 Corinthians 2, Paul writes that the Spirit reveals the mysteries of God to humans. God's divine revelation in Jesus can never be a matter of scientific psychological investigation (cf. Brümmer 2011:155). Thus, in conclusion it can be said that to distinguish God's activities - whether it is creative or revealed - in this world is not a matter of observation or perception. It requires a discernment with eyes of faith (Brümmer 2011:156).

Religious experiences should not be seen as something only extraordinary or abnormal. It should also be seen as ordinary experiences (which are observed through the senses), perceived through eyes of faith. Religious experiences should be interpreted as all those experiences of daily activities experienced though the senses, as well as all the events in the world and in history, in the light of faith. In such a way, believers should experience their communion with God as realisation of God's objectives. Jantzen (1989:301) interprets religious experiences in a wider sense - as a continuous experience of love communion with God. This consists of a transformation of life in the light of faith. This continuous relationship with God is the core and centre point of Christianity.

Pure human discernment and assessment of what is happening in everyday life can distort the experiencing of divine presence and involvement. ${ }^{25}$ Believers require education to comprehend and to pay attention to perceived stimuli in order to experience God's presence and involvement in everyday living. This is where the role and function of churches become relevant. Churches should become centres of spiritual reformation, gymnasia where believers should be educated and exercised to correct any form of perception disorders, to recognise divine involvement (Adams 2016:275). Believers must learn from one another and be introduced to techniques of contemplative prayer. Engagement with and guidance from those who live in practical partnership with God can improve any believer's

25.Almond (1982:166-167) notes that the nature of a religious experience is closely connected to the 'the content that informs it'. He also emphasised that approval has to be granted to 'those experiences which go beyond or are at odds with the received context'. He specifically pointed to powerful religious experiences that 'may lead to the creative transformation of a religious tradition' and that are 'may lead to the creative transformation of a religious tradition' and that are
'capable of generating new interpretations of the tradition' (Almond 1982:168). 
prayer life. Much can be learnt from their experiences (Adams 2016:280).

God's immanence a supernatural existential: Believers in the monotheistic religions (Islam, Christianity and Judaism) imagine God as a single figure. Nonetheless, the Old Testament describes and refers to God in many ways. ${ }^{26}$ The connotation of God with the plural in the Hebrew language (םיה) prepares the way for relating this deity with different images that describe the character of this being. God is presented in the Old Testament through 'word pictures' rather than defined by a selection of words (Mills 1998:vii): God as Law in Exodus (1998:31-43); God as Father and husband in prophecy (1998:71-82); God of power and justice in Psalms (1998:109-121). Also, in the New Testament God is referred to in many ways, similar and dissimilar from the Old Testament. ${ }^{27}$ Jesus addresses God as 'Father', and the Johannine believers are characterised as 'children of God' because they are 'born of God' (Jn 1:13; 3:3, 5; also 1 Jn). Any form of prayer awakens the spiritual senses of the believer.

Metaphors have also been used to say something about this mysterious divine being and to enable humans not only to talk about this God but also how divine involvement in creation is to be understood, and how communication with this being is viable. Biblical authors used metaphor to picture God, making sense to them in order that they could talk about God and also talk to God - which relate to the idiom of the day. Some of these are familiar to many - God as shepherd, potter or God as Father. Others are less familiar. Therefore, present-day believers shall have to add new contemporary idioms to make sense of God in their everyday living when they pray and talk with the divine.

God has chosen to reveal who God is through language and events of the ordinary everyday life that is comprehensible to believers. Nevertheless, none of any image, metaphor or event captures the whole of God because God is so completely different from humans, and therefore requires different kinds of speech. Many believers do not grasp and articulate adequately the invisible mystery of God's involvement in their lives. If they should, their metaphors about God will enable them to grow in their faith and trust about the reality of God's involvement in their lives and influence their daily prayers.

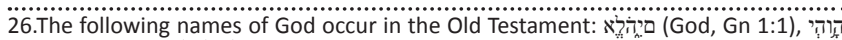

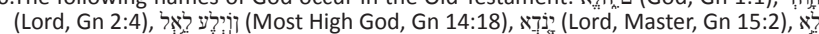

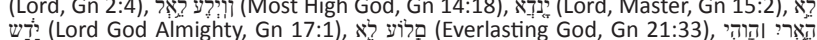

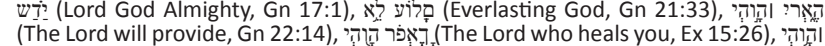

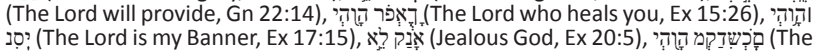

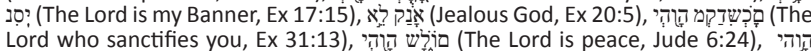

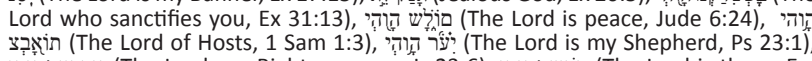

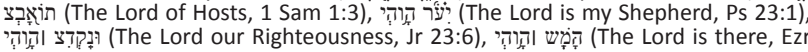

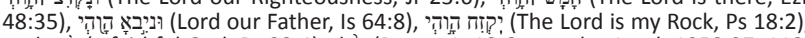

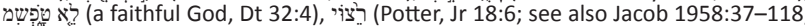
Zimmerli 1978:17-58).

27.In the New Testament the nature and character of God is presented in a number of

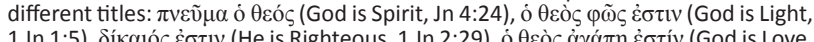

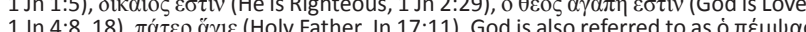
$1 \mathrm{Jn} 4: 8,18$ ), $\pi \alpha \dot{\tau} \varepsilon \rho \alpha \alpha \gamma \varepsilon$ (Holy Father, Jn 17:11). God is also referred to as o $\pi \varepsilon \mu \psi \alpha$ $\mu \varepsilon$ (the one who sent me, Jn 8:26, 29), ó үewpyóc (Vinegrower, Jn 15:1; also Is 5:5),

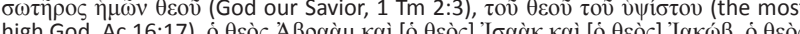

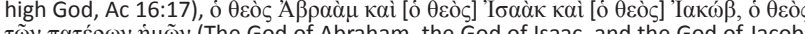

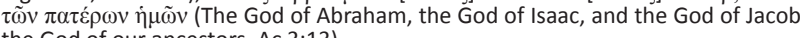
the God of our ancestors, Ac 3:13).
}

Adams (2016:280) says that ' $[p]$ rayer as a way of being in the world with God gives us our best experiential access to who God is, what God does and how God loves'. Only those who live in the world with God as their eternal life partner will be able to experience the divine presence, divine closeness and everyday divine involvement. Only those who live in the world with God will respond by praying continuously, or should we rather say, regularly. The believer's perception and experience of God will influence a believer's spirituality when praying as well as the frequency of praying.

\section{Conclusion}

Prayer and the experience of God's involvement in a believer's life constitute human-divine dialogue. The experience of God in everyday life can result in both regular planned and unplanned prayer. In Acts of the Apostles as well as in the Pauline epistles mentioned above, it is evident that Paul was a pray-er. Numerous references occur about Paul in the act of praying, and his own references indicate that he prays regularly. The experience of his daily dialogue with God and what it means to him influence him to exhort the Thessalonians to 'pray without ceasing'.

Prayers in Paul's epistles focus on salvation, the existential needs of daily living, to stand firm against evil, and the spiritual orientation to live pure and blameless lives (complete sanctification) until the parousia (1 Th 5:23). Paul experienced God, the resurrected Christ and the power of the Holy Spirit every day of his life. For Paul the experience of God is not limited to extraordinary events, but subsists essentially in ordinary, daily events. He responds to divine involvement through his prayers, through witnessing and through the writing of his epistles directed to different Christian congregations. Therefore, for Paul, prayer was to pray without ceasing, for he was in constant dialogue with God every day. For him, prayer without ceasing was a way of life. A believer's knowledge and scriptural images about God will determine how real, intense and important these experiences will be; it will determine to a great extent how the believer will live and how regularly the person will pray.

Believers must also admit that God's activity in their lives is not always obvious and easily comprehensible. The Holy Spirit enables believers spiritually to see, hear, understand and experience God's daily involvement in their lives. Prayer, then, for the believer facilitates spiritual experiences that provide continuous transformation for the one who 'prays without ceasing'. The result, for Paul, of this form of dialogue and communication between God and his church constitutes continuous joy and thankfulness.

\section{Acknowledgements Competing interests}

The author declares that he has no financial or personal relationships that may have inappropriately influenced him in writing this article. 


\section{References}

Adams, M.M., 2016, 'Prayer as the "lifeline of theology"', Anglican Theological Review 98(2), 271-283.

Almond, P.C., 1982, Mystical experience and religious doctrine: An investigation of the study of mysticism in world religions, Mouton, Berlin.

Alston, W.P., 1982, 'Religious Experience and Religious Belief', Western Division Meetings, Noûs 16(1), 3-12, viewed 03 April 2017, from http://links.jstor.org/
sici?sici=0029-4624\%28198203\%2916\%3A1\%3C3\%3AREARB\%3E2.0. Sici?sici $=002$
CO\%3B2-D

Arndt, W., Danker, F.W. \& Bauer, W., 2000, A Greek-English lexicon of the New Testament and other early Christian literature, Chicago University Press, Chicago, IL.

Batluck, M., 2011, 'Religious experience in New Testament research', Currents in Biblical Research 9(3), 339-363. https://doi.org/10.1177/1476993X10383201

Best, E., 2003, The first and second epistles to the Thessalonians, Hendrickson Publishers, Peabody, MA.

Bloomquist, L.G., 2007, 'Subverted by joy: Suffering and joy in Paul's letter to the Philippians', Interpretation 61, 270-282.

Brown, C. (ed.), 1976, Dictionary of New Testament Theology, vol. II, The Paternoster Press, Exeter.

Bruce, F.F., 1998, 1 and 2 Thessalonians, Word, Incorporated, Dallas, TX.

Brümmer, V., 2011, Wat doen ons wanneer ons bid? Ashgate Publishing Limited London.

Craffert, P.F., 2008, The life of a Galilean Shaman. Jesus of Nazareth in Anthropological Historical Perspective, Cascade Books, Eugene, OR.

Czachesz, I., 2015, 'Religious experience in Mediterranean antiquity: Introduction' Journal of Cognitive History 2(1), 5-13, https://doi.org/10.1558/jch. v2i1.30984

Davila, J.R., 2002, 'Shamanic initiatory death and resurrection in the Hekhalot literature', in P. Mirecki \& M. Meyer (eds.), Magic and ritual in the ancient world, pp. 283-302, Brill, Leiden.

Divinity \& Religion Research, 2017, Prayers of the apostle Paul, topically arranged Regent University, viewed 04 April 2017, from http://libguides.regent.edu/c. php?g $=306402 \& p=2045333$

Dunn, J.D.G., 1970, Baptism in the Holy Spirit: A re-examination of the New Testament teaching on the gift of the spirit in relation to Pentecostalism today, Studies in Biblical Theology, SCM, London.

Dunn, J.D.G., 1975, Jesus and the Spirit. A study of the religious and Charismatic experience of Jesus and the First Christians as reflected in the New Testament Eerdmans, Grand Rapids, MI.

Ellingworth, P. \& Nida, E.A., 1976, A handbook on Paul's letters to the Thessalonians, United Bible Societies, New York.

Fairbrother, E., 2016, 'From dis-bodied discipleship to embodied relationality: Experiential formation in the life of prayer', Anglican Theological Review 98(2), Experientia

Fee, G.D., 1994, God's empowering presence: The Holy Spirit in the letters of Paul, Hendrickson, Peabody, MA.

Fee, G.D., 1996, Paul The Spirit and the People of God, Hendrickson, Peabody, MA.

Ferguson, E., 2003, Backgrounds of early Christianity, Eerdmans, Grand Rapids, MA.

Friburg, T., Friburg, B. \& Miller, N.F., 2000, Analytical lexicon of the Greek New Testament, vol. 4, Baker Book House, Grand Rapids, MI.

Garrett, J.L., Jr., 1972, 'A theology of prayer', Southwestern Journal of Theology 14(2), 3-17.

Green, G.L., 2002, The letters to the Thessalonians, Eerdmans, Grand Rapids, MI.

Hardin, L.T., 2015, 'Is a Pauline spirituality still viable?', Journal of Spiritual Formation and Soul Care 82, 132-146.

Hendriksen, W. \& Kistemaker, S.J., 1953-2001, Exposition of I-II Thessalonians, Baker Book House, Grand Rapids, Ml.
Hendry, G.S., 1972, 'The lifeline of theology', Princeton Seminary Bulletin 22-30, viewed 10 April 2017, from http://journals.ptsem.edu/id/PSB1972652/ viewed 10 Ap
dmd006?page $=7$

Howard, E., 2008, The Brazos introduction to Christian spirituality, Brazos Press, Grand Rapids, MI.

Hurtado, L.W., 2000, 'Religious experience and religious innovation in the New Testament', The Journal of Religion 80(2), 183-205. https://doi.org/10.1086/ 490606

Jacob, E., 1958, Theology of the Old Testament, Harper and Row Publishers, New York.

James, W., 1902, The varieties of religious experience, From the Christian Classics Ethereal Library, viewed 16 April 2017, from https://books.google.co.za/books?id $=3 p C i D p S 8 L 2 w C \&$ printsec $=$ frontcover $\& d q=J a m e s,+W .,+1902,+$ The $+v a r i e t i e s+o f+$ religious+experience,\&hl=en\&sa=X\&redir_esc=y\#v=onepage \&q=James $\% 2 \mathrm{C} \% 20$ W. $\% 2$ C $\% 201902 \% 2$ C $\% 20$ The $\% 2$ varieties $\% 20$ of $\% 2$ religious $\% 20$ experience $\% 2 \mathrm{C} \& \mathrm{f}=$ false

Jantzen, G.M., 1989, 'Mysticism and experience', Religious Studies 25(3), 295-315. https://doi.org/10.1017/S0034412500019867

Johnson, L.T., 1998, Religious experience in earliest Christianity: A missing dimension in New Testament studies, Fortress Press, Minneapolis, MN.

Jungmann, J.A., 1976, The mass: An historical, theological and pastoral survey, The Liturgical Press, Collegeville, PA.

Larson, K., 2000, I \& II Thessalonians, I \& II Timothy, Titus, Philemon, Broadman \& Holman Publishers, Nashville, TN.

Louw, J.P. \& Nida, E.A., 1996, Greek-English lexicon of the New Testament: Based on semantic domains, vol. 1, United Bible Societies, New York.

Martin, D.M., 1995, 1, 2 Thessalonians, Broadman \& Holman Publishers, Nashville, TN.

McGee, J.V., 2002, When Paul prayed, Thru the Bible Radio Network, Pasadena, CA, viewed 03 April 2017, from http://www.ttb.org/docs/default-source/Booklets/ when-paul-prayed.pdf?sfvrsn $=2$

Mills, M.E., 1998, Images of God in the Old Testament, Casell, London, viewed 09 October 2017, from https://books.google.co.za/books?id=TImivdREOrAC\&prints ec $=$ frontcover\&dq=Images + of + God+in+the+Old + Testament\&hl=en\&sa=X\&redir esc $=y \# v=$ onepage $\& q=I$ mages $\% 20$ of $\% 20$ God $\% 20$ in $\% 20$ the $\% 200 \mid d \% 20$ Testament\&f=false

Pilch, J.J., 1996, 'Altered states of consciousness: A "Kitbashed" model', Biblical Theology Bulletin 26, 133-138.

Pilch, J.J., 2011, Flights of the soul: Visions, heavenly journeys, and peak experiences in the biblical world, Eerdmans, Grand Rapids, MI.

Räisänen, H., 1999, 'Tradition, experience, interpretation: A dialectical model for describing the development of religious thought', in T. Ahlbäck (ed.), Approaching religion, pp. 215-226, Almqvist \& Wiksell International, Stockholm.

Räisänen, H., 2000, Beyond New Testament theology: A story and a programme, 2nd edn., SCM Press, London.

Schnelle, U., 2003, Apostle Paul: His life and theology, Baker Academic, Grand Rapids, MI.

Stendahl, K., 1980, 'Paul at prayer', Interpretation 34(3), 240-249. https://doi. org/10.1177/002096438003400303

Theissen, G., 2007, Erleben und Verhalten der ersten Christen: Eine Psychologie des Urchristentums, Gütersloher Verlagshaus, Gütersloh.

Theissen, G., 2013, 'Paulus und die Mystik: Der eine und einzige Gott und die Transformation des Menschen', Zeitschrift Für Theologie Und Kirche 110(3), 263-290. https://doi.org/10.1628/004435413X666341

Wanamaker, C.A., 1990, The Epistles to the Thessalonians: A commentary on the Greek text, Eerdmans, Grand Rapids, MI.

Whittington, B.L. \& Scher, S., 2010, 'Prayer and subjective well-being: An examination of six different types of prayer', International Journal for the Psychology of Religion 20, viewed 11 April 2017, from http://works.bepress.com/steven.scher/2/

Zimmerli, W., 1978, Old Testament theology in outline, T\&T Clark, Edinburgh.

Zodhiates, S., 2000, The complete word study dictionary: New testament, AMG, Chattanooga. 